\title{
Kansas State University Memorial Stadium Green Roofs Methods
}

\section{Research Fellow:}

Lee R. Skabelund, PLA, ASLA

Associate Professor, Landscape Architecture and Regional \& Community Planning

Kansas State University

\section{Research Assistant:}

M. M. Lekhon Alam, MS.ARCH

PhD Candidate in Environmental Design and Planning

Kansas State University

\section{Firm Liaisons:}

Jeffrey L. Bruce (PLA,)

Chuck Dixon (soil scientist)

David Stokes (PLA, ASLA, ASIC, Managing Principal)

Jeffrey L. Bruce and Company

This investigation was conducted as part of the Landscape Architecture Foundation's 2020 Case Study Investigation (CSI) program. CSI matches faculty-student research teams with design practitioners to document the benefits of exemplary high-performing landscape projects. Teams develop methods to quantify environmental, social, and economic benefits and produce Case Study Briefs for LAF's Landscape Performance Series.

To cite:

Skabelund, Lee R., and M. M. Lekhon Alam. "Kansas State University Memorial Stadium Green Roofs Methods." Landscape Performance Series. Landscape Architecture Foundation, 2020. https://doi.org/10.31353/cs1691

The full case study can be found at: https://landscapeperformance.org/case-studybriefs/ksumemorial-stadium 


\section{Table of Contents}

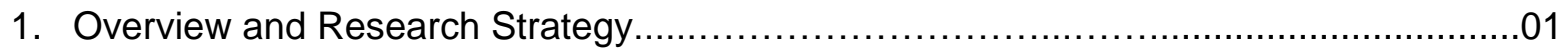

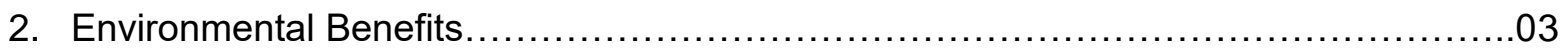

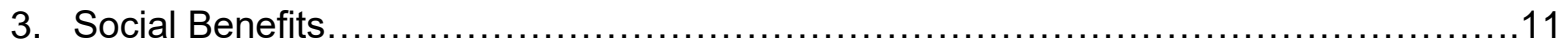

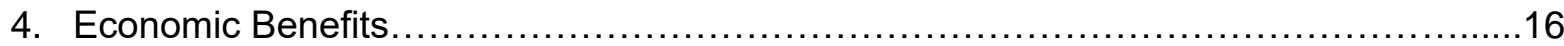

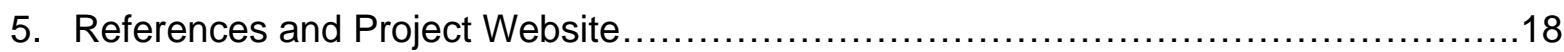

\section{Overview and Research Strategy}

\section{Overview of the Project:}

The Kansas State University (K-State) Memorial Stadium was constructed in the 1920s to honor students and alumni who sacrificed their lives during World War I (K-State, n.d.). Dedicated in 1929, Memorial Stadium was the first memorial on campus. Identical plaques commemorating veterans are located on the south ends of both West Stadium and East Stadium (K-State, n.d.). University football games were moved from Memorial Stadium to the new K-State Football Stadium (now called Bill Snyder Family Stadium) in 1967 (K-State, n.d.). Today, Memorial Stadium is used for marching band practices and high school band events, club soccer and rugby games, and many pick-up sports, exercise and relaxation.

The Memorial Stadium green roofs were completed in July 2015 (west side) and April 2016 (east side) and cost approximately $\$ 2.5$ million combined. Some of the stadium stairs (which served as informal seating prior to 2015-2016 stadium renovations) were covered by insulation and waterproofing/roof protection materials, and retrofitted with prairie-like green roofs.

The primary purpose of the two K-State Memorial Stadium green roofs is to protect the structural integrity of the two renovated buildings by creating a new waterproofing system and limiting the number of people that can gather on each rooftop. The K-State administration approved this project after considering a variety of green roof concepts developed by landscape architects, architects, engineers, and other professionals between 2008 and 2012.

K-State campus sustainability goals related to these projects included providing improved building insulation, protection of each building structure, longevity of waterproofing materials, urban heat island mitigation, stormwater management, and creation of habitat (especially for butterflies and other pollinators). To help meet these needs, regionally-derived substrates and a combination of seeds and live plants representing 25-30 native plant species were placed on these steeply sloped roofs in 2015 and 2016. The west and east Memorial Stadium green roofs cover a combined total of approximately 41,000 square feet of concrete structure.

K-State's Facilities staff provided oversight for construction of these two large green roofs in the Flint Hills Ecoregion at Manhattan, Kansas. The lead designer for these green roof projects was Jeffrey L. Bruce \& Company. Jeff Bruce led his team of landscape architects and soils/agronomy experts to design each of the prairie-like living roof ecosystems. Tim Sharp, 
project manager of landscape implementation and erosion control at Blueville Nursery, Inc. (Manhattan, Kansas), led installation of the geo-web, substrate, and irrigation systems, the living components of the two green roofs, and initial fertilization and plant management work. Studies of plant species dominance and species richness, sub-surface soil moisture and temperature changes, various pollinators, and management requirements were initiated in 2016 and continue for these two roofs. These studies are led by K-State landscape architecture faculty and students, with Lee R. Skabelund as Principal Investigator.

\section{Facing the Unprecedented COVID-19 Situation in the Year 2020:}

The research team was limited in this study because of the COVID-19 pandemic. The pandemic changed use of the Memorial Stadium dramatically after the K-State campus was closed for an approximately three-month long local community shutdown which began in mid-March and began to be phased out in mid-May 2020. Because K-State had no on-campus/in-person summer classes in 2020 and many students left Manhattan during mid-March (for an extended two-week Spring Break) and did not return until mid-to-late August (prior to Fall 2020 classes), visitor use was naturally depressed during this time period. Additionally, no user counts were conducted by our research team during the fall due to academic and research demands.

K-State took advantage of having very few people on campus and in the local community by closing Memorial Stadium during a portion of the summer of 2020. This allowed K-State to have a contractor replace the artificial turf on the playfield inside the running track at the Memorial Stadium (see Figure 1). As a result, there were very few people visiting the stadium and associated green roofs from mid-June through late July 2020. Research regarding the use of the Memorial Stadium in spring and summer 2020 by K-State students and visitors was thus severely hampered by the community and campus response to COVID-19.

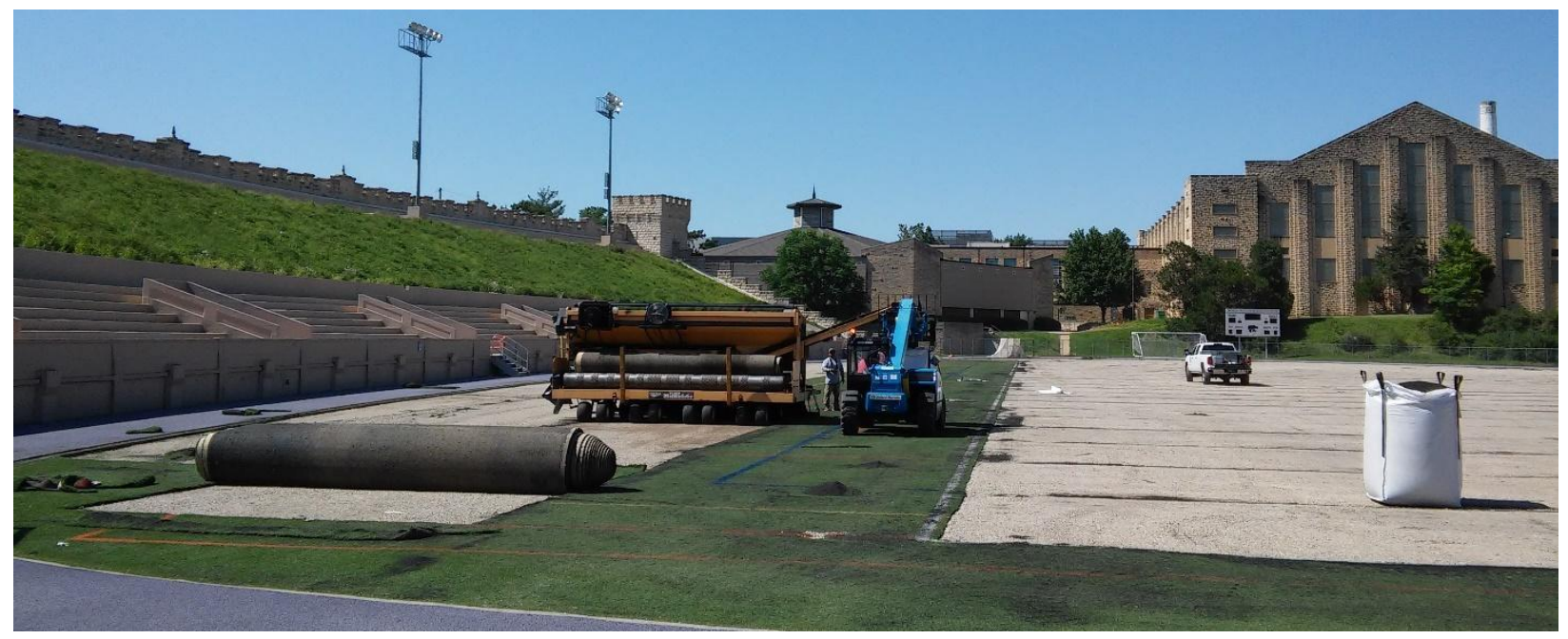

Figure 1. Photo of initiation of artificial turf removal and replacement at K-State's Memorial Stadium (unexpected by the K-State LAF-CSI research team). Photo by Lee R. Skabelund; June 12, 2020. 


\section{Two biggest challenges associated with COVID-19 pandemic circumstances:}

1. It was very difficult to connect with K-State staff and our firm liaisons due to attention by all parties on COVID-19 and related safety concerns, ongoing social justice issues, and expanded online education demands.

2. It was impossible to obtain "normal" Memorial Stadium recreational use observations due to most students leaving Manhattan in mid-March 2020 and spring to early summer stay-at-home orders for Riley County and Manhattan, Kansas - and the closure of the Memorial Stadium in June and July 2020 for artificial turf removal and replacement.

\section{Environmental Benefits:}

1. Created a healthy soil ecosystem. Green roof soil biomass increased from an average of 49.5 nanomoles per gram of substrate in 2017 to 77.4 nanomoles per gram in 2019. Organic matter increased from an average of $1.1 \%$ in 2017 to $1.65 \%$ in 2019.

\section{Soil Biomass \& Organic Matter Methods:}

Total soil biomass was determined by taking three substrate samples from each of the two Memorial Stadium green roofs in October 2017, November 2018, and June 2019 and having them analyzed by Microbial ID, Inc. in Newark, Delaware (shipping the collected green roof substrate samples in cold conditions). The average value of the six samples was calculated to obtain the average total soil biomass for the two green roofs.

The percentage of organic matter was determined by taking three substrate samples from each of the two Memorial Stadium green roofs in October 2017, November 2018, and June 2019 and having them analyzed by Ag Source Laboratories in Lincoln, Nebraska. The average value of the six samples was calculated to obtain the average estimated amount of organic matter for the two green roofs.

\section{Soil Biomass \& Organic Matter Findings:}

Memorial Stadium Green Roofs (MSGRs) soil biomass increased each year that substrate samples were analyzed: from 49.5 nanomoles per gram of substrate in October 2017, to 61.2 in November 2018, to 77.4 in June 2019. Total soil biomass ranged from an average of 34.8 nanomoles per gram of substrate on the western MSGR to 64.3 on the eastern MSGR in 2017, from 45.3 (W) to 77.0 (E) in 2018, and from 53.1 (W) to 101.7 (E) in 2019. The higher amounts of soil biomass on the eastern MSGR are likely related to the higher amounts of above-ground plant biomass (readily discerned by both visual observations and clipping of above-ground vegetative biomass in four, one-meter square plots on Aug 29, 2016, with 414 grams of biomass per plot on the east side and approximately 21 grams per plot on the west side).

Organic matter within the substrates on the two green roofs increased from the 2017 baseline value (from an average of $1.1 \%$ in 2017 to an average of $1.65 \%$ in 2018 and $1.4 \%$ in 2019). Organic matter on the eastern MSGR was $1.1 \%$ in 2017, 1.5\% in 2018, and $1.9 \%$ in 2019. Organic matter on the western MSGR was 1.1\% in 2017, 1.8\% in 2018, and $0.9 \%$ in 2019. 
Limitations: More extensive substrate sampling at different times of the year may lead to different results, so these observations are simply references that provide green roof researchers, designers, and managers with a sense of the dynamic nature of living green roof ecosystems. Comparisons between above- and below-ground biomass to air temperature, rainfall, supplemental irrigation, and sub-surface soil temperatures and moisture levels could be useful, but such analyses were beyond the scope of this study. Sub-surface green roof substrate temperature and moisture data were collected for parts of the MSGRs by K-State researchers between 2016 and 2020, however, this data was not analyzed for the LAF study.

\section{Saved an estimated 100,000 gallons of potable water and approximately \$335 from 2017 to 2020 by strategically shutting off irrigation when rain was anticipated.}

\section{Methods for Estimating Water Savings (Amount and Cost):}

Savings related to reduced potable water use is estimated by tracking soil moisture levels, then communicating with K-State Grounds staff between 2017 and 2020. These savings occurred as a result of soil moisture communications between Lee Skabelund and K-State Grounds staff. When Lee Skabelund observed moisture levels dropping below 0.05 VWC (volumetric water content) for one or more sensors, as recorded using Decagon 5TM soil moisture sensors connected to a Decagon data-logger and communicated to METER's Zentra Data Tracking website, he encouraged K-State Grounds staff to add water in the next few days if measurable rainfall was not forecast by the National Weather Service for Manhattan, Kansas.

The number of times irrigation was reduced on the green roofs due to sufficient soil moisture levels was estimated based on Lee Skabelund's personal communications (via email or call/text) regarding the need for supplemental irrigation at the MSGRs. Detailed records of rainfall kept by Lee Skabelund within 250 meters the MSGRs (using data from a rain gauge at the nearby Seaton Hall Upper Green Roof) was used to confirm dry periods at the MSGRs.

\section{July 2020 example used to estimate total savings between 2017 and 2020:}

Per Brett Robinson (7/31/2020 email to Lee Skabelund): "During peak usage, I am estimating [that we use] around 10,800 gallons a week for the west side. East stadium is a little different due to broken zones, but if running correctly [this green roof] should be the same."

Since 1 CCF $=\sim 748$ gallons, K-State saves $\sim 29$ CCF and $\sim 72$ each week during peak use when staff shut off green roof irrigation systems on the Memorial Stadium Green Roofs (as for example, Brett Robinson, K-State Grounds did 7/27/2020 to 7/31/2020 - based on Lee Skabelund's recommendation).

\section{Water Savings Calculations:}

10,800 gallons $/ 748$ gallons * 2 roofs $=28.88$ (rounded up to 29) >>> 29 CCF * $\$ 2.49$ per CCF $=\$ 72$ (72.21 rounded down to nearest whole number, using the July $2019 \mathrm{~K}$-State potable water cost rate). 
K-State saved water approximately 12 times between 2017 and 2020 by anticipating rainfall and shutting off the MSGR irrigation systems. Since precise timeframes when irrigation was shut off was not recorded, Lee Skabelund estimated that $40 \%$ of each of the 12 weeks when irrigation was shut off was the approximate amount of time when irrigation savings occurred, thus the total gallon amount was 104,121 (748 gallons * 29 CCF ${ }^{*} 12$ days * 0.4 or $40 \%$ ), rounded down to a total of 100,000 gallons saved since $40 \%$ is a rough estimate.

Limitations: Savings varied depending on Lee Skabelund's ability to anticipate expected rainfall and adequate soil moisture using local weather forecasts and MSGR soil moisture sensors, the amount of water applied to the two green roofs near the time irrigation systems were temporarily shut off, and the cost of potable water (which typically changes month-to-month).

\section{Created plant communities of high ecological quality as demonstrated by an Adjusted Floristic Quality Index (FQI) score of 25.}

\section{Plant ID Methods and Findings:}

Native plant species were identified between 2016 and 2020 via vegetation surveys along eight, 100-foot transects on each green roof, and during many green roof walkabouts by Lee Skabelund, Ryan Peters, Kyle Koehler, and Mark Mayfield. Total species richness and species dominance were documented. Pam Blackmore and Jeff Taylor identified plant species in halfmeter-square plots examined every six meters along centerline transects on the two roofs late spring to early fall in 2017 and 2018. Many native and non-native species were identified during Pam and Jeff's data collection and this data was combined with plant data collected on each green roof by other members of the K-State landscape architecture research team between 2016 and 2020. Identification of grasses and forbs nearest to a point (the end of the flag/metal pin placed into the substrate roughly every two feet) along the eight, 100-foot transects on each green roof was done by one or more of several researchers working together (Lee Skabelund, Ryan Peters, Pam Blackmore, and Jeff Taylor). Botanists Jeff Taylor and Mark Mayfield provided support in identifying plants that were unknown to Skabelund and other non-botanists.

As a result of our K-State landscape architecture research team's annual efforts to document plant species dynamics (completed in late June each year from 2016 to 2019 as led by Lee Skabelund, and completed again on July 23, 2020 by Jeff Taylor) we found that these two green roofs (approximately 42,000 square feet in combined size of vegetated area) host more than 140 native and non-native grasses and forbs (84 native Kansas grasses and forbs, and 37 nonnative plant species), including a range of woody and herbaceous plants brought to the roofs with the green roof seed mixes and live plantings, and by birds and the wind).

Limitations: Plant identification can be very difficult for non-botanists so $100 \%$ accuracy of all data collected on the MSGRs is unlikely, but this data provides a reasonable estimate of species present and those species that are most dominant on the two green roofs.

\section{Floristic Quality Index (FQI) Methods:}

The total number of identified species at the two Memorial Stadium green roofs were entered into the free, open source Universal Floristic Quality Assessment (FQA) Calculator 
(https://universalfqa.org/), allowing us to get a sense of the botanical condition or quality of the plant communities forming on these two green roofs.

The Universal FQA Calculator has the plant database prepared by (Freeman, 2012), and calculated the Adjusted Floristic Quality Index (FQI) using this well-respected state database. Adjusted FQl's include contributions of non-native species and higher species richness that is created by the presence of abundant non-native plants (Miller and Wardrop, 2006).

Limitations: Plant identification can be very difficult for non-botanists so $100 \%$ accuracy of all data collected on the MSGRs is unlikely, but this data provides a reasonable estimate of species present and those species that are most dominant on the two green roofs.

\section{Floristic Quality Index (FQI) Findings:}

The Universal FQA Calculator indicated that the Memorial Stadium green roofs have an Adjusted FQI (floristic quality) of 25, based on the total unique species identified and accepted by the online calculator. According to Wilhelm and Rericha (2017), an FQI of 20-35 indicates high vegetative quality. If all species were non-native the floristic quality would be rated as 0 .

Clearly the species planted on the two green roofs and those that came in with soils and in other ways have created reasonably rich plant communities that can be considered to be moderately high quality floristically.

Limitations: Note that the Adjusted FQI for the Memorial Stadium green roofs might be lower than 25 if the calculation was based on a one-time field assessment of all plants identified at that time, rather than the compilation of all species identified on the green roofs as of July 2020 (84 native Kansas grasses and forbs, and 37 non-native plant species).

\section{Reflections on Additional Environmental Benefits:}

Aboveground biomass is influenced by green roof implementation and management (including irrigation, fertilization, weeding, clipping, and unintentional plants arriving on the two roofs in the substrates or grow media and with seeds and live plants) and has increased year-to-year per visual observations by Lee Skabelund (except where spotty irrigation coverage has reduced aboveground vegetative biomass or where weeding, clipping and/or cotton rat disturbances have reduced vegetation cover). Belowground biomass has created abundant life (living soils that harbor cotton rats, ground-nesting bees, and many microorganisms, including different types of nematodes that were identified by K-State plant pathologist Timothy Todd after substrate samples were collected on October 22, 2019). Water-holding capacity, carbon sequestration, provision of flowers for pollinators, and reduced urban heat island effects are typically each aided by increased aboveground and belowground biomass, root growth, organic matter, vegetative coverage, and plant species diversity.

The following two photos highlight the diversity of vegetation on the two green roofs between 2016 and 2020. Figure 3 is an image taken of the West MSGR in 2020 (during the fifth growing season) while Figure 4 shows the East MSGR in 2016 (during its first growing season). 


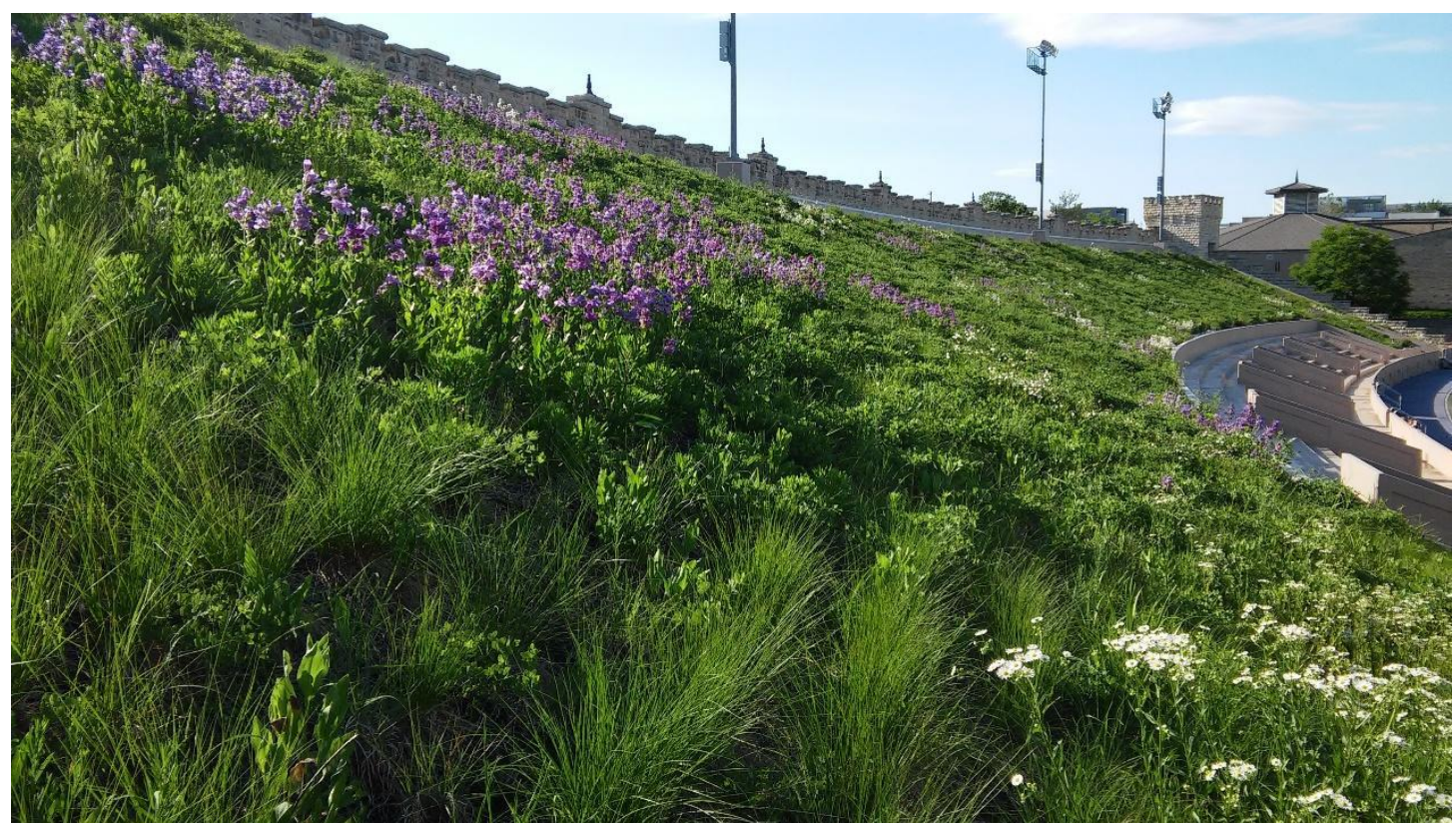

Figure 3. Photo of the West Memorial Stadium Green Roof May 29, 2020.

Photo by Lee R. Skabelund.

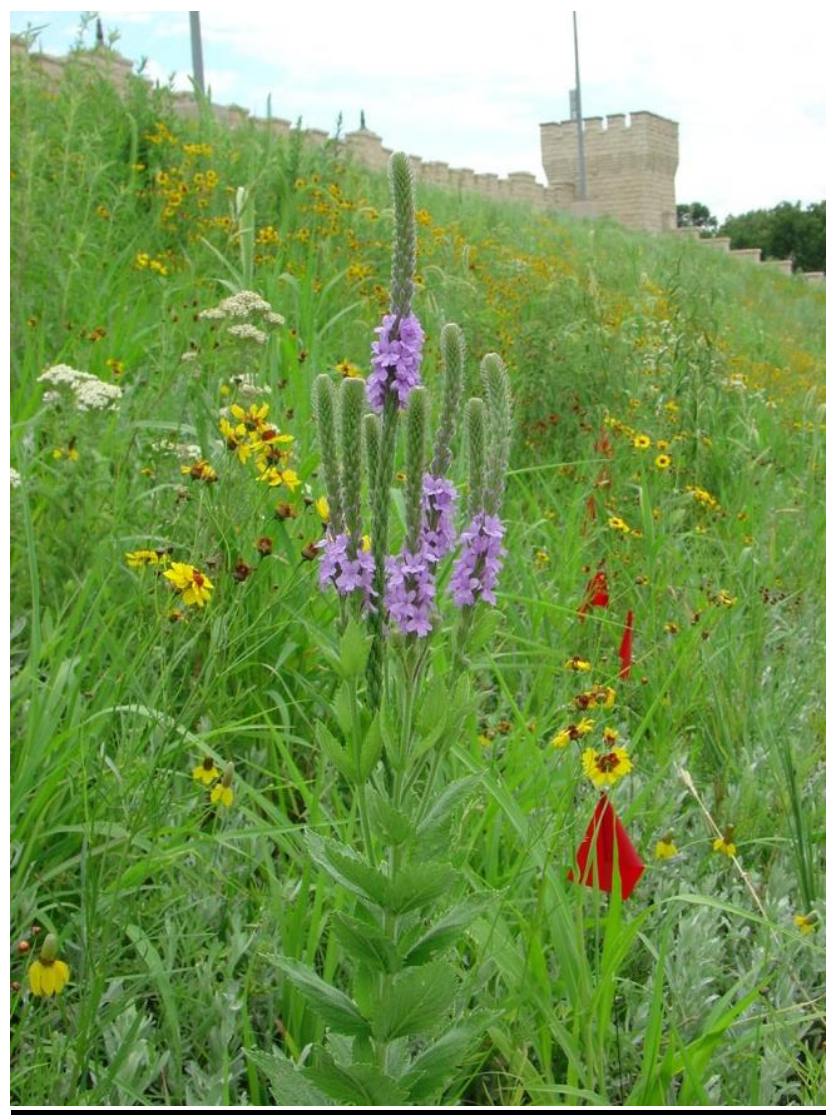

Figure 4. Photo of the East Memorial Stadium Green Roof June 30, 2016 during initial plant species identification and species dominance research (thus the red flags spaced every two feet apart). Photo by Lee R. Skabelund. 


\section{Provides native vegetation and dynamic habitat for 18 observed butterfly species including monarchs, buckeyes, and red admirals along with many other pollinators and wildlife including native Kansas bees, red-tailed hawks, cotton rats, and rabbits. The green roofs were found to attract a higher total number of butterflies than comparable natural prairies.}

\section{Butterfly ID Methods:}

Pam Blackmore completed butterfly walks (see Fig. 2) along the centerline of each green roof (north-south) 15 times during the 2017 and 2018 growing seasons, with the same number of butterfly walks at Konza Prairie and an urban prairie at Warner Park. Butterfly and plant species were documented along each green roof transect and compared to butterfly and plant species observed and documented along four transects in two different watersheds at Konza Prairie (about seven miles south of Manhattan) and two transects at the Warner Park prairie (on the west side of Manhattan, Kansas).

The observations of native Kansas bees were made by K-State entomologist Brian Spiesman, while red-tailed hawk and bird observations were made by Lee Skabelund and Pam Blackmore. K-State biologist Andrew Hope trapped and released cotton rats and observed rabbit droppings on the East MSGR.

\section{Butterfly ID Findings:}

Pam Blackmore's thesis work, which was supervised by Lee Skabelund and guided by ecologist David Haukos and botanist Jeff Taylor, showed that the green roofs actually attract more total butterflies than comparable prairie transects at Konza Prairie and Warner Park. The plant species richness is in part due to seeds being carried to the roof by contractors (in the sandy soils or substrate mix, and associated with live plants) and plant species brought by birds, wind, and perhaps small mammals.

The 18 butterfly species compare to 26 butterfly species at two watersheds at Konza Prairie and 18 species at the urban prairie on the west side of Manhattan, Kansas. Per Blackmore, the two green roofs provide a habitat to generalist butterflies (2019). Butterflies were selected for study because they are indicator species of quality pollinator habitat.

Source: BLACKMORE, P. 2019. Butterflies, tallgrass prairie, and green roofs. Unpublished Kansas State University Thesis. https://krex.k-state.edu/dspace/handle/2097/39694 


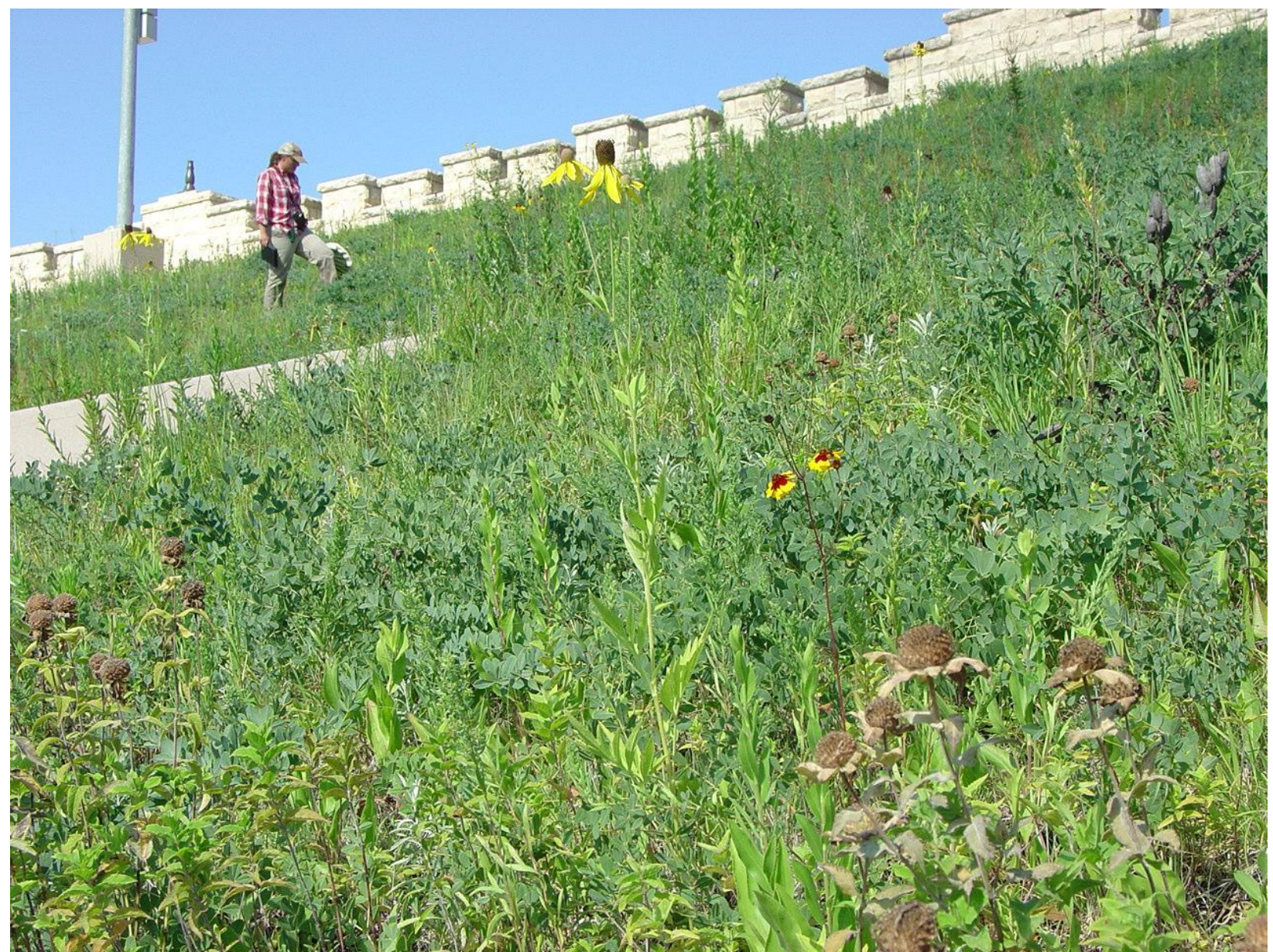

Figure 2. Photo of K-State's West Memorial Stadium Green Roof during one of Pam Blackmore's 15 butterfly walks. Photo taken by Lee R. Skabelund on July 5, 2017.

\section{Saves an estimated $16,932 \mathrm{kWh}$ and 133.5 Therms or $\$ 1,425$ annually in energy costs on each green roof as compared to a conventional dark roof, and 458.5 Therms or $\$ 90$ annually compared to a white roof.}

\section{Methods for Estimating Energy Cost Savings:}

The "Green Roof Energy Calculator" created by the Urban Climate Research Center (https://sustainability.asu.edu/urban-climate/green-roof-calculator/) at Arizona State University (ASU) was used for the calculation. This calculator incorporates the simulation results to determine predicted energy and cost savings based on the user input values for building type, location, green roof leaf area index, soil depth, and area (ASU, n.d.). The total amount of energy saved is based on the East MSGR roof specifications and averaged energy costs, interpreted using ASU's Green Roof Energy Calculator with the following soil depths and green roof area.

The K-State Memorial Stadium Green Roofs have sandy substrates (soil). The sandy soil (growing media) was laid at depths of 5 to 6 inches over insulated, steeply sloped surfaces, which are typically 20-22 degrees or 36-40 percent. Vegetated portions of each roof are around 
1,950 square meters or 21,000 square feet, totaling around 3,900 square meters or 42,000 square feet. Including rock edging each roof size is 2,052 square meters (22,090 square feet).

\section{LAI (Leaf Area Index) Calculation for MSGRs: (LAI value = 3.5)}

The LAI value is an essential input (value) for the "Green Roof Energy Calculator" developed by Dr. David Sailor at Portland State University. We first sought to understand the meaning of LAI and then find a reasonable LAI value for the Memorial Stadium Green Roofs. We did this by completing a literature review to determine the most appropriate LAI value for this type of steeply-sloped green roof system.

Key findings from the Leaf Area Index (LAI) literature:

1. LAl of less than 1 means there is bare ground that is not covered completely by vegetation (leaves). Per Siegmann (2017), a soil area may be covered with one layer of leaves $(L A I=1)$ or more. Thus, for three layers of leaves $L A I=3$.

2. LAI values range from 0 (bare ground) to more than 10 ("dense conifer forests") as per Chen and Black (1992). Zhang et al. (2019) indicate that many shallow soil (extensive) green roofs typically have LAI values between 1.0 and 3.0.

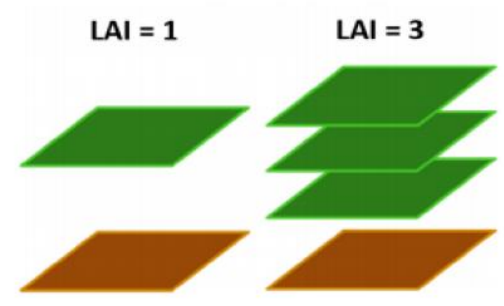

Figure 6: A schematic structure of an extensive green roof and an intensive green roof, and the cooling mechanism in the daytime. Diagram from Zhang et al. (2019).

Leaf Area Index (LAI) Value is estimated to be 3.5

- According to Yu (2006) and Tabares Velasco (2009), the LAl for a rooftop garden, especially for an intensive green roof ranges from 1.0 to 6.0 (or up to 7.0) depending on the species of plants. The MSGRs (both east and west) are semi-intensive green roofs, with the East MSGR having more biomass.

- LAl values for extensive green roofs (substrate/soil thickness of less than 6") are typically around 1.0 to 3.0 (Tabares Velasco, 2009). The average depth of MSGR soils (substrates) is estimated to be 5.5 inches.

- Therefore, our estimation is that the average MSGR (east and west) LAI value is 3.5 (approximately 3.0 on the West MSGR and 4.0 on the East MSGR).

The following information was used in the Green Roof Energy Calculator:

1. The location and type of building = closest city and building type ("Topeka, Kansas" and "Old Office Building"). Note: The nearest city data available was Topeka, Kansas, which 
has a similar climate but is slightly wetter (on average) than the K-State Memorial Stadium location which is 50 miles to the west in Manhattan, Kansas.

2. Surface Area of each Memorial Stadium Green Roof - 22,090 square feet

3. Depth of Growing Media - $\mathbf{5 . 5}$ inches (average soil depth for the two green roofs)

4. Leaf Area Index (LAl) $\mathbf{- 3 . 5}$ (average for the two green roofs)

5. The percentage of plant coverage $-95 \%$ (shading the roof surface)

6. Albedo for non-vegetated areas $\mathbf{- 0 . 1 5}$ (darker, absorptive surfaces)

The online calculator (https://prod.aws.gios.asu.edu/greenroofcalculator/grcalc v2.php) then provided the estimated savings reported.

\section{Notes:}

- Electricity rates for the state of Kansas were based on the U.S. Department of Energy's Average Retail Price, which was $\$ 0.0851 / \mathbf{k W h}$ (rounded to 0.08 by the calculator).

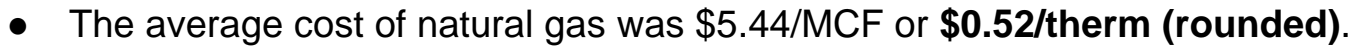
(Note that 1,000 cubic feet [MCF] of natural gas equals 1.037 MMBtu or 10.37 Therms.)

- Utility prices vary month to month so estimated cost savings will change year to year. Refer to K-State utility rates here: www.k-state.edu/facilities/energy/utility-rates.html

\section{Social Benefits:}

\section{Provides a backdrop for some 20,000 unique stadium users each year, helping to make connections to the nearby prairie ecosystems.}

\section{User-Count Methods:}

Because our two-person research team was not able to meet together between mid-March and early summer 2020 due to the COVID-19 pandemic, Lee Skabelund and Lekhon Alam observed social activities on their own at the Memorial Stadium Green Roofs (MSGRs) once or twice every week or two (or longer). During these visits we noted the number of users (visitors at the Memorial Stadium) and took photos to document the social use of the Memorial Stadium. We determined a distinct time period from 5:00 to 7:00 pm on selected sunny weekdays (the expected time of peak use of the Memorial Stadium) and collected data on seleceted sunny weekends (Saturdays or Sundays).12 official observational visits occurred prior to K-State's 2020 summer break in mid-May and one time at the end of May (May 29, 2020).

We collected user data February 28 \& 29, March 21, 25 \& 31, April 1, 9, 11, 18 \& 25, and May 6 $\& 29,2020$. All user numbers are approximate due to the large size of area and only having one observer at the Memorial Stadium during a specific data collection visit. Anyone visiting the Memorial Stadium for more than five minutes was included in the user count.

Based on past informal observations by research team-leader Lee Skabelund, as temperatures increased during the spring of 2016, 2017, 2018, and 2019, numbers of users also tended to increase because of increasing participation in both formal (organized team) and informal sports and other cultural and social activities. Because of the dramatic changes in Memorial Stadium use we decided that interviews with K-State Band staff would be important. Of particular interest was use of the Memorial Stadium by K-State Band members and other bands 
(refer to the "Band use" below). Also of primary interest was use of the Memorial Stadium for specific educational purposes (refer to the "Educational use" section below).

February to May 2020 user counts are provided in the "User Count Findings" table below.

\section{User Count Findings (February to May 2020):}

\begin{tabular}{|c|c|c|c|}
\hline Date & $\begin{array}{l}\text { Number of } \\
\text { People }\end{array}$ & Activities & Remarks \\
\hline Feb 28, 2020 & $\sim 60$ & Playing, running, walking, talking & Before COVID-19 Pandemic \\
\hline Feb 29, 2020 & $\sim 150$ & Playing, running, walking, talking & Before COVID-19 Pandemic \\
\hline Mar 21, 2020 & $\sim 20$ & Playing, running, walking, talking & $\begin{array}{c}\text { During COVID-19 Pandemic } \\
\text { (After Local Stay at Home Order) }\end{array}$ \\
\hline Mar 25, 2020 & $\sim 42$ & Playing, running, walking, talking & During COVID-19 Pandemic \\
\hline Mar 31, 2020 & $\sim 30$ & Playing, running, walking, talking & During COVID-19 Pandemic \\
\hline Apr 1, 2020 & $\sim 25$ & Playing, running, walking, talking & During COVID-19 Pandemic \\
\hline Apr 9, 2020 & $\sim 18$ & Playing, running, walking, talking & During COVID-19 Pandemic \\
\hline Apr 11, 2020 & $\sim 5$ & Playing, running, walking, talking & During COVID-19 Pandemic \\
\hline Apr 18, 2020 & $\sim 15$ & Playing, running, walking, talking & During COVID-19 Pandemic \\
\hline Apr 25, 2020 & $\sim 25$ & Playing, running, walking, talking & During COVID-19 Pandemic \\
\hline May 6, 2020 & $\sim 40$ & Playing, running, walking, talking & During COVID-19 Pandemic \\
\hline May 29, 2020 & $\sim 25$ & Playing, running, walking, talking & During COVID-19 Pandemic \\
\hline Average & $37.9(\sim 38)$ & & \\
\hline
\end{tabular}

Table Notes and User Count Data Limitations: All but two of the observations were made during the COVID-19 pandemic. There was a significant difference in user numbers before and after the COVID-19 pandemic began, largely due to stay-at-home orders and many students leaving Manhattan to complete the spring semester online. Data was not collected throughout the entire day when observations were made. No data was collected prior to 2020, and the spring 2020 and summer 2020 semesters were both very abnormal due to COVID-19 and the dramatic reduction of students, faculty, and staff on campus and in the community.

To supplement these observations, which cannot be considered typical, the number of unique users annually was estimated by Lee Skabelund as a rough "ballpark guess" and represents a best estimate of unique users visiting the Memorial Stadium each year between 2016 and 2019. It includes K-State Marching Band members and support staff ( 450 users), high school band members ( 2,000 users), and spectators ( 1,050 users). Also other athletic events, weddings, meetings at the Alumni Center, and other special events ( 5,500 users) and those exercising at or using the stadium for other purposes, including passersby ( 11,000 users). 


\section{Band Use Calculation Methods:}

Data was collected from Dr. Frank Tracz, Professor of Music and Director of Bands at Kansas State University, through a virtual Zoom meeting and then exchanging email messages with meeting notes attached. Lee Skabelund and Lekhon Alam interviewed Dr. Tracz in July 2020, and Dr. Tracz provided all necessary information regarding the use of the K-State Memorial Stadium for band-related activities during the interview and then by subsequently reviewing the data we compiled from our three-way conversation.

\section{Band Use Calculation Details and Findings:}

- Total estimated K-State Band numbers (students \& support staff) $=450$ each year

- Total estimated high school band members (students \& staff) =2,000 each year

- Total estimated unique spectators at band events $=1,050$ each year

- Total K-State Band use of the stadium over 4 years $(2016-2019)=105,600$ user days (user day/visits = part of a specific day when the stadium is used by an individual user)

- Total K-State Band spectators/visitors (2,250 each year $\times 4$ years) $=9,000$ visits

- Other Band-Related Activities (high school band events at the stadium) =13,600 visits

- GRAND TOTAL band-related visits (user days) = 105,600 + 9,000 + 13,600 = 128,200 (rounded to 128,000 over 4 years for an average of 32,000 visits each year)

Note: Per Dr. Trancz (K-State Band Director), the two green roofs generally complement the use of the Memorial Stadium by members of the band (see Fig. 7): "The green roofs look very nice. As a gardener, I enjoy them-and am impressed at the plant growth on the steep slopes. We must dodge or fight bees at times. It is soothing to watch \& hear the sprinklers."

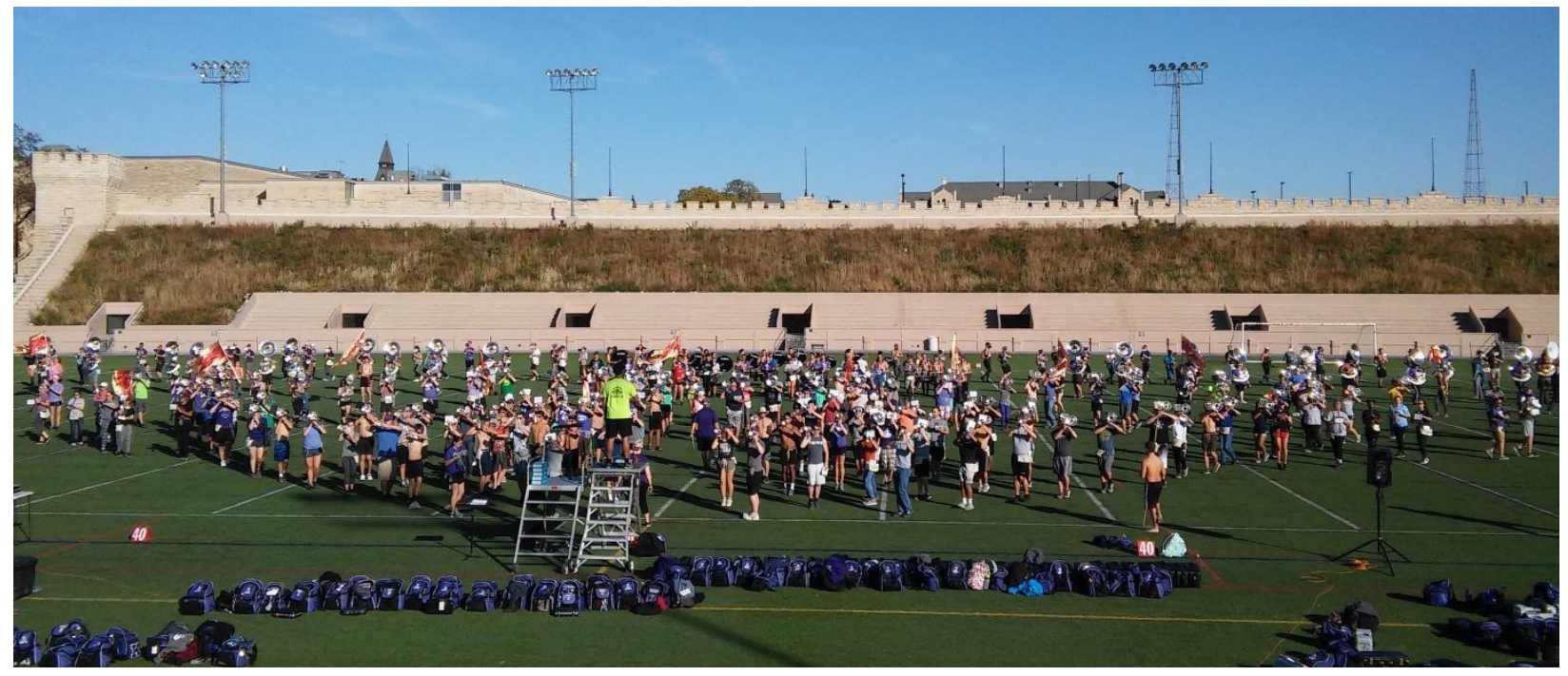

Figure 7. Photo of K-State's East Memorial Stadium Green Roof as a backdrop to a K-State Band practice. Photo taken by Lee R. Skabelund on October 23, 2018. 


\section{Educated an estimated 1,100 people about the Memorial Stadium Green Roofs from 2015 to 2020.}

\section{Educational Use Methods:}

One of the most important social benefits of the two green roofs is their educational value. Participation numbers related to educational events and activities were gathered from Kansas State University faculty and students. The MSGRs have been the focus of active research and volunteer vegetation management since the summer of 2016 by Professor Lee R. Skabelund and K-State students (including Ryan Peters, Kyle Koehler, Pam Blackmore, Allyssa Decker, Lekhon Alam, Richard Colwell, and others).

The Landscape Architecture Foundation's Case Study Investigation (CSI) program caused Professor Skabelund to dig deeply into his project records to gather information related to educational benefits related to the green roofs. These records included class presentations and conference papers, email conversations, typed and hand-written notes, and site photographs. Professor Skabelund and his research assistant Lekhon Alam also contacted KSU faculty members to inquire how they and their students have used or learned from the Memorial Stadium green roofs for educational purposes.

\section{Educational Use Findings:}

Regular research work, class discussions, conference presentations, green roof tours, and other activities engage faculty, students, professionals and visitors in learning from the two dynamic Memorial Stadium green roofs. Based on Professor Skabelund's records and personal conversations with other K-State faculty who discuss the green roofs in their classes, our research team (Skabelund and Alam) estimate that the number of people educated about these created ecosystems to be approximately 1,100 between the Fall of 2015 and mid-summer 2020. The green roofs have also been a place where many professionals, K-State faculty, students, and staff, and other community members and visitors have learned about created green roof ecosystem dynamics, landscape architecture design, and associated building renovations. One example is shown in Figure 8, one of many MSGR "living roof tours" given by Lee Skabelund and/or his graduate research assistants. 


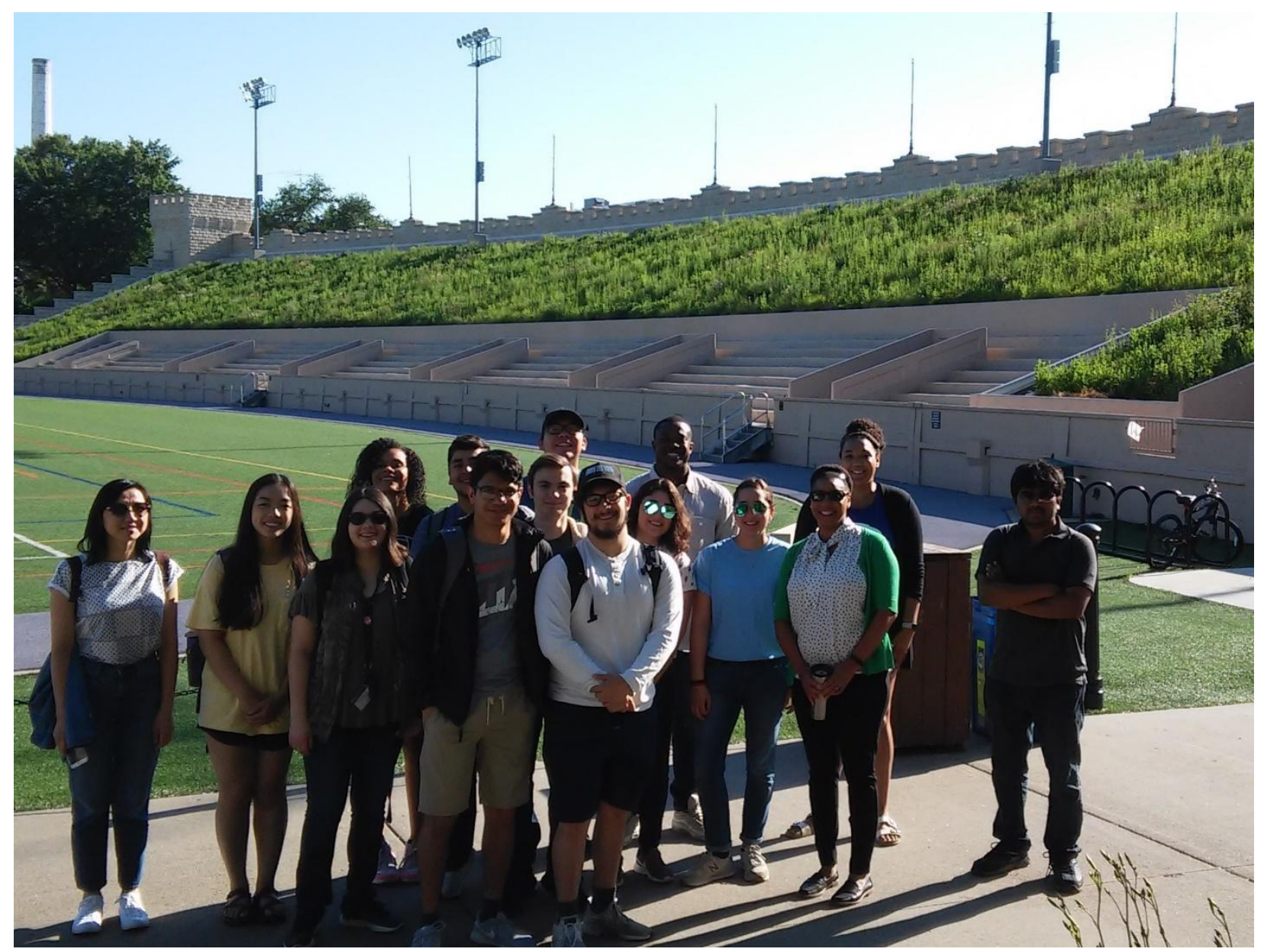

Figure 8. Photo of the East Memorial Stadium Green Roof June 13, 2019 during an educational event where three green roof researchers shared observations with a group of scholars visiting the K-State campus to learn the purpose of the two green roof and about our ongoing plant, pollinator, and soil moisture monitoring, our multi-year green roof maintenance observations, and our regular vegetation management efforts. Photo by Lee R. Skabelund.

\section{KSU Departments and Programs studying or learning the MSGRs include:}

- Landscape Architecture (Lee Skabelund, Pam Blackmore, Lekhon Alam, and others)

- Biological \& Agricultural Engineering (Dr. Trisha Moore \& Dr. Stacy Hutchinson)

- Entomology (Dr. Brian Speisman \& Dr. Tania Kim)

- Horticulture (Dr. Greg Davis \& Dr. Cathie Lavis)

- Biology (Dr. Andrew Hope)

As noted above, at least five Kansas State University departments and programs use the Memorial Stadium green roofs (MSGR) for conducting research or for educational purposes. MSGR education occurs in multiple courses at Kansas State University (typically involving 200-300 students annually from different colleges, departments, and programs). 


\section{Academic research and class activities include:}

- Tours for K-State students, faculty, staff, and visitors (including 2018 and 2019 K-State Open House events, and special tours by a range of students and visitors).

- Class visits, presentations/discussions (including Landscape Architecture plants \& planting design classes and Bio-Ag Engineering and Environmental Design classes).

- Special events and presentations (including Earth Week events, special green roof educational events at the Purple Masque Theatre, and the 2 November 2018 Green Roof Research Synopsis).

- Volunteer vegetation management work by faculty, students \& community members.

- Research work and the green roofs (discussed at ten conferences).

Other educational activities include conversations with the design team, weeding and counting weeds, measuring soil moisture levels, documenting plant species dominance and changes over time, assessing pollinator use, collecting and analyzing soil/substrate samples, and discussing operations and management issues with K-State Facilities and Grounds staff.

\section{Economic Benefits:}

Economic benefits are very modest (even small) but were deemed to be helpful to examine by the research team. Engagement by faculty and students reduces nuisance plants arriving on the roof, thus helping to protect the economic investments made in these two living roofs.

Perhaps the greatest value to the university has come in support for research by Mary K. Jarvis funds to support faculty and student research, donations of money and in-kind-time by external partners such as Jeff Bruce, Chuck Dixon, and their team, financial and in-kind support given to Pam Blackmore for her two-year butterfly research, funding from K-State's Green Action Fund to support green roof education and outreach efforts, and support by many others on and offcampus between 2016 and 2020.

\section{Saved an estimated $\$ 5,400$ in weeding costs through volunteer work by $K$ - State students and faculty.}

\section{Methods for Estimating Savings from Volunteer Weeding:}

The amount of money saved by the university was estimated by looking at Lee Skabelund's volunteer weeding records (including his email correspondence and notes on his calendar regarding weeding efforts, and photographs of volunteer weeding efforts). Sources of data include Figure 9, taken in late May 2019 during a late spring workday. 


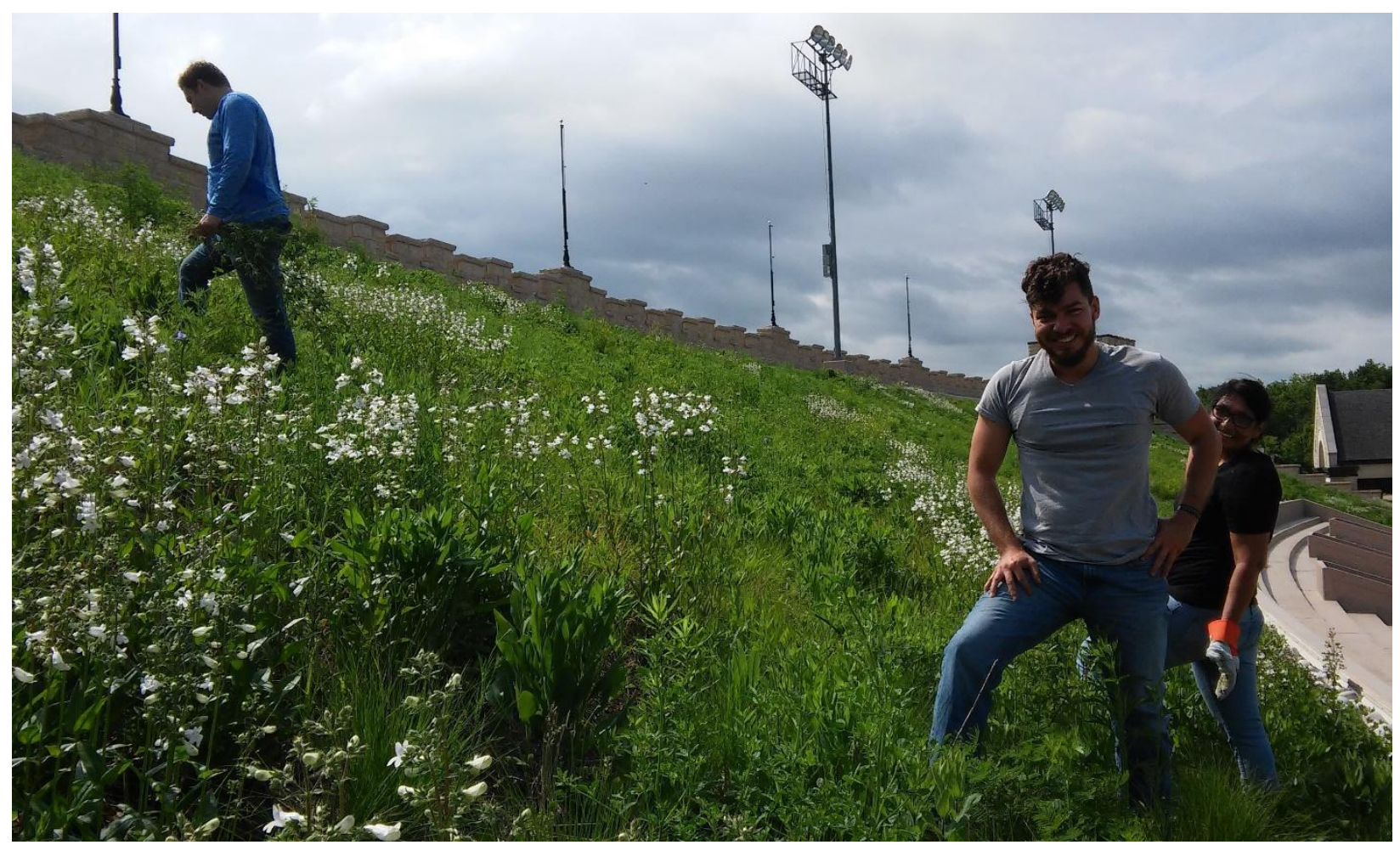

Figure 9. Photo of the East Memorial Stadium Green Roof May 25, 2019 during a weeding event with two K-State student volunteers, a local resident, and one K-State faculty member. This was one of many volunteer weeding events led by Lee Skabelund between 2016 and 2020. Photo by Lee R. Skabelund.

\section{Estimating Savings from Volunteer Weeding:}

The total amount of money saved by the university as the result of volunteer weeding between 2016 and summer 2020 (including about 55 hours of Lee Skabelund's time, and another 19 hours by students \& residents) is estimated to be $\$ 5,425$.

- $55 \times \$ 90 / \mathrm{hr}=\$ 4,950+19+\$ 25 / \mathrm{hr}=\$ 475-$ Total in Maintenance savings to K-State $\$ 5,425$

Annual maintenance costs estimated by the current director of K-State Grounds range between $\$ 3,000$ and $\$ 8,500$ each year (largely depending on the extent of irrigation repairs).

- K-State Annual Maintenance Costs: $\$ 3,000$ - $\$ 8,500$

- Irrigation repairs - $\$ 500$ to $\$ 6,000$ (depends on the extent of repairs; in 2020, repairs estimated at $>\$ 6 k)$

- Fertilization (to help activate living soils) - $\$ 1,000$ to $\$ 1,080$ (payment to green roof sub-contractor Blueville Nursery)

- Clipping \& Treating Woodies - $\$ 500$ (by K-State Grounds staff)

- Coordination by K-State Grounds Director - \$1,000 (20 hrs x \$50/hr) 


\section{References \& Project Websites:}

ASU. n.d. Background on the [Green Roof Energy] Calculator [Online]. Available at: https://prod.aws.gios.asu.edu/greenroofcalculator/calculator info v2.php [Accessed, along with the hyperlinked calculator, 18 June 2021].

BLACKMORE, P. 2019. Butterflies, tallgrass prairie, and green roofs. Unpublished Kansas State University Thesis. https://krex.k-state.edu/dspace/handle/2097/39694

CHEN, J. M. \& BLACK, T. A. 1992. Defining leaf area index for non-flat leaves. Plant, Cell \& Environment, 15, 421-429.

FREEMAN, C. C. 2012. Coefficients of conservatism for Kansas vascular plants (2012) and selected life history attributes. Unpublished Kansas Biological Survey \& R.L. McGregor Herbarium report. University of Kansas.

GREENROOFS.COM. n.d. KANSAS STATE UNIVERSITY (KSU) MEMORIAL STADIUM GREEN ROOFS [Online]. Available at: https://www.greenroofs.com/projects/kansasstate-university-ksu-memorial-stadium-green-roofs/ [Accessed 18 June 2021].

K-STATE. n.d. Memorial Stadium [Online]. Available at: https://www.k-state.edu/about/historytraditions/memorials/memorial-stadium/ [Accessed 18 June 2021].

MILLER, S. J. \& WARDROP, D. H. 2006. Adapting the floristic quality assessment index to indicate anthropogenic disturbance in central Pennsylvania wetlands. Ecological indicators, 6, 313-326.

SIEGMANN, B. 2017. Hyperspectral Remote Sensing for Winter Wheat Leaf Area Index Assessment in Precision Agriculture.

SKABELUND, L. R., BLACKMORE, P., DECKER, A. \& SHRESTHA, P., n.d. Kansas State University Green Roofs Overview | KSU Memorial Stadium Green Roofs [Online]. Available at: https://www.k-state.edu/greenroofs/ | https://www.kstate.edu/greenroofs/memorial.html [Accessed 18 June 2021].

SKABELUND, L. R., DECKER, A., MOORE, T., SHRESTHA, P. \& BRUCE, J. L. 2017. Monitoring two large-scale prairie-like green roofs in Manhattan, Kansas. Cities Alive $15^{\text {th }}$ Annual Green Roof \& Wall Conference: Seattle | September 18-21, 2017, Session 22: Research Track paper. Available at: https://www.kstate.edu/greenroofs/images/pdf docs/CitiesAlive2017 Skabelund Decker Paper13Se p2017.pdf [Accessed 18 June 2021].

TABARES VELASCO, P. C. 2009. Predictive heat and mass transfer model of plant-based roofing materials for assessment of energy savings. Unpublished Pennsylvania State University Architectural Engineering Dissertation. Available at: https://etda.libraries.psu.edu/files/final submissions/4957 [Accessed 18 June 2021].

WILHELM, G. \& RERICHA, L. 2017. Flora of the Chicago region: A floristic and ecological synthesis. Indiana Academy of Science Indianapolis, Indiana, USA.

YU, C. 2006. The intervention of plants in the conflicts between buildings and climate: A case study in Singapore. Unpublished National University of Singapore PhD Thesis. Available at: https://core.ac.uk/download/pdf/48629576.pdf [Accessed 18 June 2021].

VAN DER MERWE, SKABELUND, L. R., SHARDA, A., BLACKMORE, P. \& BREMER, D. 2017. Towards characterizing green roof vegetation using color-infrared and thermal sensors. Cities Alive 15 $5^{\text {th }}$ Annual Green Roof \& Wall Conference: Seattle | September 18-21, 2017, Session 12: Research Track paper. Available at: https://www.kstate.edu/greenroofs/images/pdf docs/CitiesAlive2017 VanDerMerwe Skabelund Pap er 22Aug2017.pdf [Accessed 18 June 2021].

ZHANG, G., HE, B. J., ZHU, Z. \& DEWANCKER, B. J. 2019. Impact of morphological characteristics of green roofs on pedestrian cooling in subtropical climates. International journal of environmental research and public health, 16, 179. 